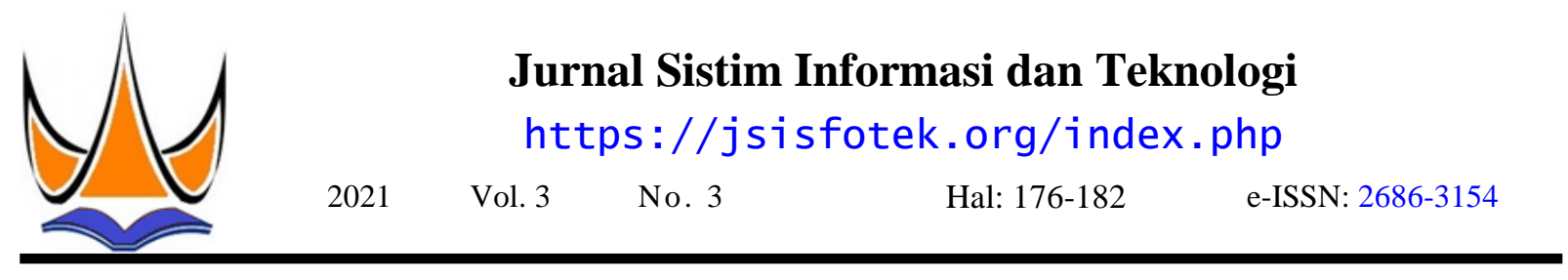

\title{
Prediksi Pencapaian Target Peserta Keluarga Berencana Pasca Persalinan menggunakan Algoritma Backpropagation
}

\author{
Stefani Hardiyanti Putri ${ }^{1 凶}$, Yuhandri ${ }^{2}$, Gunadi Widi Nurcahyo ${ }^{3}$, \\ ${ }^{1,2,3}$ Universitas Putra Indonesia YPTK Padang \\ stefanihardiyanti19@gmai1.com
}

\begin{abstract}
Population growth in Indonesia continues to increase, so the government makes a program to control the rate of growth of the population, namely the Family Planning Program (KB). The implementation of family planning also has another objective, namely to reduce the risk of maternal death after childbirth. To measure the level of increasing target achievement of postpartum family planning participants. So that it can be a reference for the DPPKBP3A in carrying out the postpartum family planning program. Data from the Population Control, Family Planning, Women Empowerment and Child Protection (DPPKBP3A) District Lima Puluh Kota data processed in this study is data on the achievement of postpartum family planning participants from 2018 to 2020. Data processing uses the Backpropagation algorithm through several stages, namely the stage initialization, activation stage, weight training (weight change) and iteration stage. One of the results obtained from the calculation is the comparison of the target with the output gradient error in Suliki District in 2018, namely the target of 0.11311 and the result of the error gradient output is -0.1171 . The prediction results obtained from this process become a reference for the Population Control, Family Planning and Women Empowerment and Child Protection Agency (DPPKBP3A) of District Lima Puluh Kota to implement the implementation of postpartum family planning programs to the community the following year.
\end{abstract}

Keyword: Prediction, Family Planning, Postpartum, DPPKBP3A, Backpropagation.

\begin{abstract}
Abstrak
Pertumbuhan penduduk di Indonesia yang terus meningkat, sehingga pemerintah membuat suatu program untuk mengendalikan laju pertumbuhan pendudukan yaitu Program Keluarga Berencana (KB). Penerapan KB juga memiliki tujuan lain yaitu menurunkan resiko kematian ibu pasca persalinan. Untuk mengukur tingkat peningkatkan pencapaian target peserta KB pasca persalinan. Sehingga dapat menjadi rujukan pihak DPPKBP3A dalam menjalankan program peserta KB pasca persalinan. Data Dinas Pengendalian Penduduk, Keluarga Berencana, Pemberdayaan Perempuan dan Perlindung Anak (DPPKBP3A) Kabupaten Lima Puluh Kota yang diolah dalam penelitian ini berupa data pencapaian target peserta KB pasca persalinan tahun 2018 sampai dengan tahun 2020. Pengolahan data menggunakan algoritma Backpropagation melalui beberapa tahapan yaitu tahap insialisasi, tahap aktivasi, weight training (perubahan bobot) dan tahap iterasi.Salah satu hasil yang didapatkan dari perhitungan adalah perbandingan target dengan error gradient output di Kecamatan Suliki tahun 2018 yaitu target 0,11311 dan hasil error gradient output $-0,1171$. Hasil prediksi yang didapatkan dari proses tersebut menjadi rujukan Dinas Pengendalian Penduduk, Keluarga Berencana Pemberdayaan Perempuan dan Perlindungan Anak (DPPKBP3A) Kabupaten Lima Puluh Kota untuk menerapkan pelaksanaan program KB pasca persalinan kepada masyarakat tahun selanjutnya.
\end{abstract}

Kata Kunci: Prediksi, Keluarga Berencana, Pasca Melahirkan, DPPKBP3A, Backpropagation.

(C) 2021 JSisfotek

\section{Pendahuluan}

Teknologi Informasi digunakan juga dalam bidang pengendalian penduduk atau dikenal dengan Badan Kependudukan dan Keluarga Berencana Nasional (BKKBN) . Pertumbuhan penduduk di Indonesia yang terus meningkat, sehingga pemerintah membuat suatu program untuk mengendalikan laju pertumbuhan pendudukan yaitu Program Keluarga Berencana (KB) [1]. Program KB ini diterapkan bertujuan untuk meningkatkan kuantitas penduduk dan mewujudkan keluarga kecil yang berkualitas. Penerapan KB juga memiliki tujuan lain yaitu menurunkan resiko kematian ibu pasca persalinan [2].

Diterima: 13-03-2021 | Revisi: 31-03-2021 | Diterbitkan: 30-09-2021 |DOI: 10.37034/jsisfotek.v3i3.62
Prediksi adalah perkiraan beberapa kebutuhan di masa depan untuk memenuhi permintaan barang dan jasa yang memperhatikan kriteria harga, kuantitas, waktu, tempat, dan kualitas [3]. Salah satu program Keluarga Berencana adalah menggunakan alat kontrasepsi untuk mengatur dan memberi jarak kehamilan [4]. Pedoman pelaksanaan kontrasepsi pasca persalinan diuraikan jenis-jenis kontrasepsi, secara umum hampir semua alat kontrasepsi dapat digunakan sebagai metode $\mathrm{KB}$ pasca persalinan [5]. Jaringan Saraf Tiruan (JST) adalah model komputasi paralel yang terdiri dari unit pemrosesan adaptif yang saling berhubungan, ditandai dengan kecenderungan untuk belajar dari pengalaman 
sebelumnya dan juga menemukan pengetahuan baru adalah nilai akurasi sebesar 99,78\% dan nilai rata-rata [6]. Cara kerja jaringan syaraf tiruan dilihat dari jumlah kesalahan (Mape) sebesar $0.23 \%$, sehingga hasil yang lapisan (layer) dan jumlah neuron. Neuron-neuron didapat bisa dijadikan rujukan dalam melakukan tersebut terkumpul di dalam lapisan-lapisan yang manajemen jumlah produksi air [16]. disebut neuron layers [7]. Neuron adalah bagian dasar pemrosesan informasi yang terdapat di dalam jaringan saraf tiruan [8]. Backpropagation mulai dikenal pada tahun 1974 oleh Paul Werbos, tahun 1982 David Parker melakukan pengembangan, dan Rumelhart dan McCelland mengembangkan lagi pada tahun 1986 [9]. Backpropagation merupakan salah satu metode yang cukup baik dalam melakukan peramalan. Penggunaan metode ini akan mendapatkan hasil yang diinginkan karena algoritma Backpropagation memungkinkan untuk menghindari kesulitan dengan menggunakan aturan pembelajaran yang mirip dengan plastisitas lonjakan waktu yang bergantung pada sinapsis [10]. Jaringan saraf tiruan Backpropagation adalah struktur jaringan saraf tiga lapis atau multilayer yaitu lapisan masukan, lapisan tersembunyi, dan lapisan keluaran. Lapisan tersembunyi bisa mempunyai lebih dari satu lapisan [11]. Korespondensi internodal secara efektif mencirikan properti pemetaan nonlinier dari Backpropagation, memungkinkan jaringan untuk mengungkapkan mekanisme dan prinsip masalah nonlinier yang kompleks [12]. Operasi neuron artifisial mencakup elemen non-linier dengan fungsi aktivasi dan dua parameter, yaitu bobot (W) dan bias (b) [13].
Data input dan output yang dipakai untuk melatih pemrosesan Backpropagation sampai memperoleh bobot penimbang (weight) yang diinginkan [14].

Sumber Data penelitian ini dari dokumen kepabeanan Ditjen Bea dan Cukai yaitu Pemberitahuan Ekspor Barang (PEB) dan Pemberitahuan Impor Barang (PIB). Variabel yang digunakan dalam data ini ada 7, antara lain: Tahun, ekspor minyak mentah, impor minyak mentah, ekspor hasil minyak, impor hasil minyak, ekspor gas dan impor gas. Penelitian ini menggunakan Lima model arsitektur yaaitu: 12-5-1, 12-7-1, 12-8-1, 12-10-1 dan 12-14-1. Arsitektur yangterbaik dari lima model yang digunakan, adalah 12-5-1, menghasilkan tingkat akurasi 83\%, MSE 0,0281641257 dan tingkat error yang dihasilkan sebesar 0,001-0,05. Model 12-5-1 bagus digunakan untuk memprediksi volume ekspor dan impor migas di Indonesia, karena tingkat akurasinya antara $80 \%$ hingga $90 \%$ [15].

Penulis akan membahas mengenai (JST) dengan peramalan jumlah prediksi air yang terjadi pada PDAM yang ada di kota Padang. Algoritma Backpropagation melatih dan menguji pola jaringan yang terbentuk dari beberapa variabel dilihat dari aspek penggunaan dan jumlah air yang terjual. Proses Algoritma
Backpropagation bertujuan untuk menghasilkan nilai akurasi dari sebuah peramalan. Hasil peramalan jumlah produksi air dengan algoritma Backpropagation,
Prediksi harga di gunakan perhitungan menggunakan algoritma Backpropagation Proses dalam algoritma Backpropagation yaitu input data, melakukan tahap normalisasi /transformasi data, iterasi, pelatihan dan menentukan parameter jaringan, kalkulasi error, mendapatkan hasil prediksi. Penentuan jumlah layer pada lapisan input, lapisan tersembunyi dan lapisan output, dilakukan untuk perancangan arsitektur JST. Pengujian dalam penelitian ini menggunakan Matlab R2013a dengan metode Backpropagation. Penentuan input, error dan perubahan bobot berguna untuk menghasilkan nilai prediksi harga kopi. Hasil prediksi harga kopi dari harga aktual 74205 ke hasil harga prediksi 73668 dengan akurasi 99.9928, harga aktual 73892 ke harga prediksi 73175 dengan akurasi 99.9903, harga aktual 77981 ke hasil prediksi 77481 akurasi 99.9936 [17].

Berdasarkan penjelasan ketiga penelitian diatas, penulis melakukan penelitian tentang prediksi pencapaian target Keluarga Berencana (KB) pasca persalinan. Data yang digunakan dalam penelitian ini adalah Data Dinas Pengendalian Penduduk, Keluarga Berencana Pemberdayaan Perempuan dan Perlindungan Anak (DPPKBP3A) Kabupaten Lima Puluh Kota, yang di olah dalam penelitian ini berupa data pencapaian target peserta KB pasca persalinan tahun 2018 sampai dengan tahun 2020. Pengolahan data menggunakan algoritma Backpropagation melalui beberapa tahapan yaitu tahap insialisasi, tahap aktivasi, merubah bobot dari input layer ke hidden layer, merubah bobot hidden layer ke output layer, dan tahap iterasi. Pengujian data di lakukan menggunakan program prediksi pencapaian target $\mathrm{KB}$ pasca persalinan.

\section{Metodologi Penelitian}

Proses dalam penyelesaian penelitian melewati berbagai rangkaian kegiatan yaitu identifikasi masalah, analisa masalah, menuntukan tujuan, pemahaman literatur, pengumpulan data, normalisasi data, penerapan metode algoritma Backpropagation, pengujian dan hasil prediksi. Rangkaian kegiatan dalam metodologi penelitian bertujuan agar proses penelitian dapat terarah pada tujuan yang telah ditentukan dan mencapai hasil yang telah ditetapkan. Hasil yang dicapai dari rangkaian kegiatan metodologi penelitian dapat menjadi solusi dari masalah yang diteliti. Rangkaian kegiatan penelitian tersebut digambarkan pada kerangka kerja penelitian yang dapat dilihat pada Gambar 1.

Jurnal Sistem Informasi dan Teknologi Vol . 3 No. 3 (2021) 176-182 




Gambar 1. Kerangka Kerja Penelitian

data yang telah diberi nilai tersebut dilakukan normalisasi data karena data berupa bilangan bulat maka diubah menjadi bilangan berkoma karena dalam sistem ini menggunakan fungsi aktivasi sigmoid biner yang memiliki range yaitu $0<\mathrm{x}<1$. Hasil normalisasi data didapatkan kemudian dilakukan proses perhitungan menggunakan sistem berulang kali sampai mendekati target yang telah ditentukan.

\subsection{Normalisasi Data}

Data awal peserta KB pasca persalinan tahun 2018 sampai tahun 2020 dilakukan normalisasi. Normalisasi data dilakukan karena dalam proses algoritma Backpropagation menggunakan fungsi aktivasi sigmoid biner yang memiliki range yaitu $0<\mathrm{x}<1$. Nilai maksimal dalam fungsi aktivasi sigmoid biner adalah 1, sehingga data awal berupa bilangan bulat diubah menjadi bilangan berkoma dengan range $[0,1]$. $[0,9]$ menggunakan rumus yang disajikan pada Persamaan (1).

2.1 Inisialisasi variabel dan beri nilai awal pada setiap variabel

$X n=0,8 * \frac{(x-a)}{(b-a)}+0,1$

Memberikan inisialisasi simbol dan nilai awal pada
setiap variabel yang di gunakan dalam proses perhitungan menggunakan algoritma Backpropagation. Di mana 0,8 merupaka ketetapan, Xn untuk Variabel dalam Backpropagation yaitu : variabel input, Normalisasi data, $x$ untuk data yang akan variabel bobot, variabel bias, variabel output target dinormalisasi, $a$ untuk nilai terkecil dari data semua awal, dan variabel learning rate. input, dan $b$ untuk nilai terbesar dari semua data input.

\subsection{Tahap Aktivasi}

Tabel 1. Hasil Normalisasi Data Tahun 2018

Pada tahap aktifasi dilakukan perhitung output aktual di hidden layer $\left(\mathrm{y}_{\mathrm{h}}\right)$ dan output aktual di output layer $\left(\mathrm{y}_{\mathrm{o}}\right)$.

\subsection{Weight training(perubahan bobot)}

Pada tahap Weight training dilakukan perhitungan eror gradient pada output layer $\left(\delta_{\mathrm{o}}\right)$, perubahan bobot dari hidden layer $\mathrm{ke}$ output layer $\left(\mathrm{U}_{\mathrm{bc}}\right)$, eror gradient pada Hara hidden layer $\left(\delta_{\mathrm{h}}\right)$, dan perubahan bobot dari unit input Pangkalan layer ke hidden layer $\left(\mathrm{U}_{\mathrm{ab}}\right.$,

\subsection{Tahap Iterasi (hasil)}

Koto Baru

Kapur IX

Gunung

Omeh

Proses perhitungan dari tahap aktivasi dan weight Lareh Sago

training (perubahan bobot) yang dilakukan secara berulang-ulang sampai mendapatkan hasil yang telah ditentukan.

\section{Hasil dan Pembahasan}

\section{Halaban}

Situjuah

Limo Nagari

Mungka

Bukik

Barisan

\begin{tabular}{|c|c|c|c|c|}
\hline \multicolumn{4}{|c|}{ Jenjang Faskes KB } & \multirow{2}{*}{ Target } \\
\hline $\begin{array}{c}\text { Faskes } \\
\text { KB } \\
\left(D_{a} 1\right)\end{array}$ & $\begin{array}{c}\text { Praktik } \\
\text { Dokter } \\
\left(\mathrm{D}_{\mathrm{a}} 2\right)\end{array}$ & $\begin{array}{l}\text { Praktik } \\
\text { Bidan } \\
\text { Mandiri } \\
\left(D_{a} 3\right) \\
\end{array}$ & $\begin{array}{l}\text { Lainnya } \\
\left(\mathrm{D}_{\mathrm{a}} 4\right)\end{array}$ & \\
\hline 0,1087 & 0,100 & 0,1008 & 0,1000 & 0,1131 \\
\hline 0,1183 & 0,100 & 0,1000 & 0,1349 & 0,1568 \\
\hline 0,2844 & 0,103 & 0,2853 & 0,1760 & 0,5546 \\
\hline 0,1157 & 0,101 & 0,1340 & 0,1498 & 0,2049 \\
\hline 0,1953 & 0,100 & 0,1375 & 0,1000 & 0,2355 \\
\hline 0,1122 & 0,100 & 0,1061 & 0,1104 & 0,1306 \\
\hline 0,8143 & 0,1043 & 0,1227 & 0,1550 & 0,9000 \\
\hline 0,1323 & 0,1043 & 0,1017 & 0,1000 & 0,1437 \\
\hline 0,2433 & 0,100 & 0,2477 & 0,1000 & 0,3972 \\
\hline 0,1262 & 0,102 & 0,1174 & 0,1000 & 0,1480 \\
\hline 0,2792 & 0,100 & 0,1000 & 0,1043 & 0,2879 \\
\hline 0,1918 & 0,1008 & 0,1349 & 0,1000 & 0,2311 \\
\hline 0,2206 & 0,1070 & 0,2189 & 0,1332 & 0,3841 \\
\hline
\end{tabular}

Proses analisa dan perancangan dilakukan untukmengetahui hasil prediksi menggunakan algoritma 3.2 Backpropagation

Backprpagation. Sistem yang akan dibuat adalah sistem untuk memprediksi peningkatan target peserta pengguna $\mathrm{KB}$ pasca persalinan di Kabupaten Lima Puluh Kota. Proses kerja dari sistem ini berdasarkan data peserta KB pasca persalinan tahun 2018 sampai dengan tahun 2020. Proses awal dari sistem prediksi menggunakan algoritma Backpropagation adalah menetukan dan memberi nilai awal pada variabel yang

Tahapan proses perhitungan algoritma Backpropagation adalah rangkaian proses yang menggunakan variabel dan rumus matematis untuk mendapatkan hasil atau target yang telah ditentukan. Tahapan dalam proses perhitungan prediksi pencapaian target peserta KB pasca persalinan di Kabupaten Lima Puluh Kota menggunakan algoritma Backpropagation. akan diproses perhitunganya dengan sistem, kemudian 
Penjelasan dari tahapan proses perhitungan algortima Backpropagation adalah sebagai berikut :

\subsubsection{Inisialisasi variabel dan beri nilai awal pada setiap variabel}

Proses awal dalam algoritma Backpropagation adalah melakukan inisialisasi dan pemberian nilai pada variabel-variabel yang akan digunakan dalam proses perhitungan. Variabel-variabel yang terdapat dalam penelitian ini sebagai berikut :

\section{a. Variabel input}

Variabel input adalah variabel yang digunakan sebagai masukan dalam proses perhitungan. Nilai input diberikan dari data data KB pasca persalinan DPPKBP3A Kabupaten Lima Puluh Kota tahun 2018 sampai 2020. Input dalam penelitian ini ada 4 (empat) yang diperoleh dari data KB pasca persalinan DPPKBP3A Kabupaten Lima Puluh Kota tahun 2018 sampai 2020. Variabel Input dapat dilihat pada Tabel 2 .

Tabel 2. Variabel Input

\begin{tabular}{llc}
\hline Variabel Input & \multicolumn{1}{c}{ Keterangan } & $\begin{array}{c}\text { Nilai Data KB } \\
\text { Pasca Persalinan } \\
\text { tahun 2018 }\end{array}$ \\
\hline$D_{a} 1$ & Faskes KB & 0,1087 \\
$D_{a} 2$ & Praktek Dokter & 0,1000 \\
$D_{a} 3$ & Praktek Bidan Mandiri & 0,1008 \\
$D_{a} 4$ & Lainnya & 0,1000 \\
\hline
\end{tabular}

b. Variabel Bobot

Nilai variabel bobot diberikan dengan angka random (acak). Variabel bobot dalam algoritma Backpropagatioan terbagi menjadi dua yaitu bobot pada input layer ke hidden layer dan bobot pada hidden layer ke output layer. Variabel bobot pada input layer ke hidden layer dapat dilihat pada Tabel 3 dan Variabel bobot pada hidden layer ke output layer disajikan pada Tabel 3 dan Tabel 4.

Tabel 3. Variabel Bobot Input Layer ke Hidden Layer

\begin{tabular}{ccc}
\hline $\begin{array}{c}\text { Variabel } \\
\text { Bobot }\end{array}$ & \multicolumn{1}{c}{ Keterangan } & $\begin{array}{c}\text { Nilai } \\
\text { Bobot }\end{array}$ \\
\hline$U_{a b} 15$ & Bobot input layer ke hidden layer 1 & 0,25 \\
$U_{a b} 25$ & Bobot input layer ke hidden layer 1 & 0,46 \\
$U_{a b} 35$ & Bobot input layer ke hidden layer 1 & 0,61 \\
$U_{a b} 45$ & Bobot input layer ke hidden layer 1 & 0,87 \\
$U_{a b} 16$ & Bobot input layer ke hidden layer 2 & 0,73 \\
$U_{a b} 26$ & Bobot input layer ke hidden layer 2 & 0,59 \\
$U_{a b} 36$ & Bobot input layer ke hidden layer 2 & 0,33 \\
$U_{a b} 46$ & Bobot input layer ke hidden layer 2 & 0,15 \\
\hline
\end{tabular}

Tabel 4. Variabel bobot pada hidden layer ke output layer

\begin{tabular}{ccc}
\hline $\begin{array}{c}\text { Variabel } \\
\text { Bobot }\end{array}$ & Keterangan & $\begin{array}{c}\text { Nilai } \\
\text { Bobot }\end{array}$ \\
\hline$U_{b c} 57$ & Bobot hidden layer 1 ke output layer & 0,28 \\
$U_{b c} 67$ & Bobot hidden layer 2 ke output layer & 0,97 \\
\hline
\end{tabular}

c. Variabel Bias

Nilai variabel bias diberikan dengan angka random $Y_{h 2}=0,5906$

(acak). Variabel bias dibagi menjadi dua yaitu bias pada hidden layer dan bias pada output layer. Variabel bias digunakan pada proses aktivasi untuk menghitung output aktual pada output layer dan output aktual pada hidden layer. Variabel bias disajikan pada Tabel 5.

Tabel 5. Variabel bias

\begin{tabular}{clc}
\hline Variabel Bias & \multicolumn{1}{c}{ Keterangan } & Nilai Bias \\
\hline$B_{h 1}$ & Bias pada hidden layer 1 & 0,56 \\
$B_{h 2}$ & Bias pada hidden layer 2 & 0,18 \\
$B_{o}$ & Bobot pada output layer & 0,42 \\
\hline
\end{tabular}

\section{d. Variabel Output Target Awal}

Nilai variabel output target awal ditentukan lebih tinggi dari data KB pasca persalinan DPPKBP3A Kabupaten Lima Puluh Kota tahun 2018 sampai 2020, hal tersebut bertujuan agar mendapatkan hasil prediksi yang lebih tinggi dari tahun sebelumnya, sehingga bisa menjadi rujukan untuk menjalakan program $\mathrm{KB}$ pasca persalinan tahun selanjutnya. Variabel output target awal digunakan dalam proses Weight training (perubahan bobot) untuk menghitung eror gradient pada output layer. Variabel output target awal adalah $O_{t}$ dengan nilai 0,11311 .

\section{e. Variabel Learning Rate}

Nilai variabel learning rate diberikan dengan angka random (acak). Variabel learning rate digunakan dalam proses Weight training (perubahan bobot). Variabel learning rate adalah $\alpha$ dengan nilai 0,5 .

\subsubsection{Tahap Aktivasi}

Tahap aktivasi adalah proses yang digunakan untuk menghitung nilai output aktual. Nilai output aktual yang dihitung dalam proses aktivasi ada dua yaitu:

a. Hitung output aktual pada hidden layer $1\left(Y_{h l}\right)$

$Y_{h l}=$ Sigmoid $\left[B h+\sum_{a=1}^{p} D a \cdot U a b\right]$

$Y_{h l}=$ Sigmoid $\left[B_{h 1}+\left(\mathrm{D}_{\mathrm{a} 1} \cdot \mathrm{U}_{\mathrm{ab} 15}\right)+\left(\mathrm{D}_{\mathrm{a} 2} \cdot \mathrm{U}_{\mathrm{ab} 25}\right)+\right.$

$$
\left.\left(D_{a 3} \cdot U_{a b 35}\right)+\left(D_{a 4} \cdot U_{a b 45}\right)\right]
$$

$Y_{h l}=$ Sigmoid $[0,56+(0,1087.0,25)+(0,1.0,46)+$ $(0,100874317.0,61)+(0,1.0,87)$

$Y_{h l}=\operatorname{Sigmoid}(0,7817)$

$Y_{h 1}=0,6860$

b. Hitung output aktual pada hidden layer $2\left(Y_{h 2}\right)$

$$
Y_{h 2}=\text { Sigmoid }\left[B h+\sum_{a=1}^{p} D a \cdot U a b\right]
$$

$$
Y_{h 2}=\text { Sigmoid }\left[B_{h 2}+\left(\mathrm{D}_{\mathrm{a} 1} \cdot \mathrm{U}_{\mathrm{ab} 16}\right)+\left(\mathrm{D}_{\mathrm{a} 2} \cdot \mathrm{U}_{\mathrm{ab} 26}\right)+\right.
$$

$$
\left.\left(\mathrm{D}_{\mathrm{a} 3} \cdot \mathrm{U}_{\mathrm{ab} 36}\right)+\left(\mathrm{D}_{\mathrm{a} 4} \cdot \mathrm{U}_{\mathrm{ab} 46}\right)\right]
$$

$Y_{h 2}=$ Sigmoid $[0,18+(0,1087.0,73)+(0,1.0,59)+$ $(0,100874317.0,33)+(0,1.0,15)]$

$$
Y_{h_{2}}=\text { Sigmoid }(0,3666)
$$


c.Hitung output aktual di output layer $\left(Y_{o}\right)$

$Y_{o}=$ Sigmoid $\left[B o+\sum_{b=1}^{q} Y h . U b c\right]$

$Y_{o}=$ Sigmoid $\left[B_{o}+\left(Y_{h 1} \cdot U_{b c 57}\right)+\left(Y_{h 12} \cdot U_{b c 67}\right)\right]$

$Y_{o}=$ Sigmoid $[0,42+(0,6860.0,28)+(0,5906$. 0,97)

$Y_{o}=$ Sigmoid $(1,1850)$

$Y_{o}=0,7658$

3.2.3 Weight Training (perubahan bobot)

Weight training adalah proses untuk memperbaharui atau merubah bobot yang ada pada hidden layer dan output layer. Proses perubahan bobot di dalam Backpropagation dihitung dengan 4 tahap yaitu :

a. Hitung eror gradient pada output layer $\left(\delta_{0}\right)$.

$$
\begin{aligned}
& \delta_{o}=\left(O_{t}-Y_{o}\right) \cdot\left(Y_{o}\right) \cdot\left[1-Y_{o}\right] \\
& \delta_{o}=(0,11311-0,7658) \cdot(0,7658) \cdot(1-0,7658) \\
& \delta_{o}=-0,1171
\end{aligned}
$$

b. Hitung perubahan bobot dari hidden layer ke output layer $\left(\mathrm{U}_{\mathrm{bc}}\right)$.

$$
\begin{aligned}
& \Delta U_{b c 57}=\alpha . Y_{o} . \delta_{o} \\
& \Delta U_{b c 57}=0,5.0,7658 .-0,1171 \\
& \Delta U_{b c 57}=-0,0402
\end{aligned}
$$

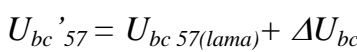

$$
\begin{aligned}
& U_{b c}{ }^{\prime} 57=0,28+-0,0402 \\
& U_{b c}{ }^{\prime}{ }^{\prime}=0,2398 \\
& \Delta U_{b c 67}=\alpha . Y_{o} . \delta_{o} \\
& \Delta U_{b c 67}=0,5.0,7658 .-0,1171 \\
& \Delta U_{b c 67}=-0,0402 \\
& U_{b c}{ }^{\prime}{ }^{\prime}=U_{b c 67(\text { lama })}+\Delta U_{b c} \\
& U_{b c}{ }^{6}{ }^{6}=0,97+-0,0402 \\
& U_{b c}{ }^{\prime}{ }^{\prime}=0,9354
\end{aligned}
$$

c. Hitung eror gradient pada hidden layer $\left(\delta_{\mathrm{h}}\right)$.

$$
\begin{aligned}
& \delta_{h 1}=Y_{h 1} \cdot\left[1-Y_{h 1}\right] \cdot \sum_{\mathrm{c}=1}^{\mathrm{p}} \delta \mathrm{o} \cdot \mathrm{Ubc}^{\prime} \\
& \delta_{h 1}=Y_{h 1} \cdot\left[1-Y_{h 1}\right] \cdot\left(\delta_{o} \cdot U_{b c}{ }^{\prime}\right) \\
& \delta_{h 1}=0,6860 \cdot[1-0,6860] \cdot(0,7658 \cdot 0,2398) \\
& \delta_{h 1}=-0,006 \\
& \delta_{h 2}=Y_{h 2} \cdot\left[1-Y_{h 2}\right] \cdot \sum_{\mathrm{c}=1}^{\mathrm{p}} \delta \mathrm{o} \cdot \mathrm{Ubc}^{\prime} \\
& \delta_{h 2}=Y_{h 2} \cdot\left[1-Y_{h 2}\right] \cdot\left(\delta_{o} \cdot U_{b c}{ }_{67}\right) \\
& \delta_{h 2}=0,5906 \cdot[1-0,5906] \cdot(0,7658 \cdot 0,9354) \\
& \delta_{h 2}=-0,0265
\end{aligned}
$$

$$
\begin{aligned}
& U_{a b 25}{ }^{\prime}=U_{a b 25 \text { (lama) }}+\Delta U_{a b 25} \\
& U_{a b 25}{ }^{\prime}=0,46+(-0,0003) \\
& U_{a b 25}{ }^{\prime}=0,4597 \\
& \Delta U_{a b 35}=\alpha \cdot D_{a 3} \cdot \delta_{h 1} \\
& \Delta U_{a b 35}=0,5.0,100874317 .(-0,006) \\
& \Delta U_{a b 35}=0,0121 \\
& U_{a b 35}{ }^{\prime}=U_{a b 35(\text { lama })}+\Delta U_{a b 35} \\
& U_{a b 35}{ }^{\prime}=0,61+(0,0121) \\
& U_{a b 35}{ }^{\prime}=0,6221 \\
& \Delta U_{a b 45}=\alpha \cdot D_{a 4} \cdot \delta_{h l} \\
& \Delta U_{a b 45}=0,5.0,1 .(-0,006) \\
& \Delta U_{a b 45}=-0,0003 \\
& U_{a b 45}{ }^{\prime}=U_{a b 45 \text { (lama) }}+\Delta U_{a b 45} \\
& U_{a b 45}{ }^{\prime}=0,87+(-0,0003) \\
& U_{a b 45}{ }^{\prime}=0,8697 \\
& \Delta U_{a b 16}=\alpha \cdot D_{a 1} . \delta_{h 2} \\
& \Delta U_{a b 16}=0,5.0,1087 .(-0,0265) \\
& \Delta U_{a b 16}=-0,00144 \\
& U_{a b 16}{ }^{\prime}=U_{a b 16(\text { lama })}+\Delta U_{a b 16} \\
& U_{a b 16}{ }^{\prime}=0,73+(-0,00144) \\
& U_{a b 16}{ }^{\prime}=0,7286 \\
& \Delta U_{a b 26}=\alpha \cdot D_{a 2} \cdot \delta_{h 2} \\
& \Delta U_{a b 26}=0,5 \cdot 0,1 \cdot(-0,0265) \\
& \Delta U_{a b 26}=-0,00132 \\
& U_{a b 26}{ }^{\prime}=U_{a b 26(\text { lama })}+\Delta U_{a b 26} \\
& U_{a b 26}{ }^{\prime}=0,59+(-0,00132) \\
& U_{a b 26}{ }^{\prime}=0,5887
\end{aligned}
$$




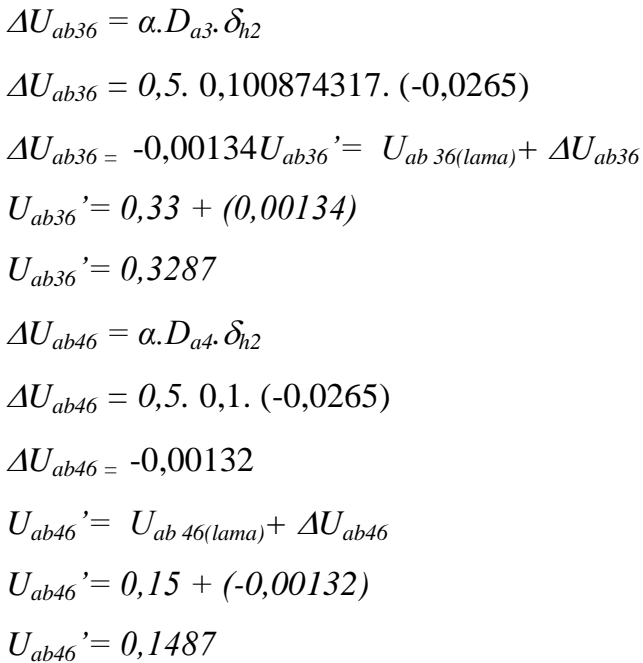

\subsubsection{Proses Iterasi (hasil)}

Proses iterasi adalah proses perhitungan tahap aktivasi dan weight training (perubahan bobot) yang dilakukan secara berulang-ulang sampai mendapatkan target atau hasil yang telah ditentukan. Penentuan pencapaian hasil prediksi adalah perbandingan antara target awal dengan error gradient output, di mana semakin kecil hasil error gradient output dari target awal maka target pengguna KB pasca persalinan dapat dicapai. Salah satu hasil yang didapatkan dari perhitungan manual di atas adalah perbandingan target dengan error gradient output di Kecamatan Suliki tahun 2018 yaitu target 0,11311 dan hasil error gradient output $-0,1171$. Hasil perhitungan data KB pasca persalinan Kabupaten Lima Puluh Kota tahun 2018 disajikan pada Tebel 6.

Tabal 6. Tabel Hasil Prediksi Tahun 2018

\begin{tabular}{clcc}
\hline No & \multicolumn{1}{c}{ Kecamatan } & $O_{t}$ & $\left(\delta_{o}\right)$ \\
\hline 1 & Suliki & 0,11311 & $-0,1171$ \\
2 & Guguak & 0,15683 & $-0,1091$ \\
3 & Payakumbuh & 0,55464 & $-0,0385$ \\
4 & Luak & 0,20492 & $-0,1004$ \\
5 & Harau & 0,23552 & $-0,0947$ \\
6 & Pangkalan Koto Baru & 0,1306 & $-0,1139$ \\
7 & Kapur IX & 0,9000 & 0,0186 \\
8 & Gunung Omeh & 0,14372 & $-0,1114$ \\
9 & Lareh Sago Halaban & 0,39727 & $-0,0659$ \\
10 & Situjuah Limo Nagari & 0,14809 & $-0,1106$ \\
11 & Mungka & 0,28798 & $-0,0852$ \\
12 & Bukik Barisan & 0,23115 & $-0,0955$ \\
13 & Akabiluru & 0,38415 & $-0,0682$ \\
& & & \\
\hline
\end{tabular}

Berdasarkan Tabel 6 yang merupakan hasil perhitungan peserta $\mathrm{KB}$ pasca persalinan dari tahun 2018 didapatkan hasil prediksi peserta KB pasca persalinan yaitu perbandingan antara target awal dengan error gradient output, di mana semakin kecil hasil error gradient output dari target awal maka target pengguna KB pasca persalinan dapat dicapai. Salah satu hasil yang didapatkan dari perhitungan adalah perbandingan target dengan error gradient output di Kecamatan Suliki tahun 2018 yaitu target 0,11311 dan hasil error gradient output $-0,1171$.

\section{Kesimpulan}

Berdasarkan tabel hasil perhitungan peserta KB pasca persalinan dari tahun 2018 sampai dengan tahun 2020 didapatkan hasil prediksi peserta $\mathrm{KB}$ pasca persalinan yaitu perbandingan antara target awal dengan error gradient output, di mana semakin kecil hasil error gradient output dari target awal maka target pengguna KB pasca persalinan dapat dicapai. Salah satu hasil yang didapatkan dari perhitungan adalah perbandingan target dengan error gradient output di Kecamatan Suliki tahun 2018 yaitu target 0,11311 dan hasil error gradient output -0,1171. Hasil prediksi yang didapatkan dari proses tersebut menjadi rujukan Dinas Pengendalian Penduduk, Keluarga Berencana Pemberdayaan Perempuan dan Perlindungan Anak (DPPKBP3A) Kabupaten Lima Puluh Kota untuk menerapkan pelaksanaan program KB pasca persalinan kepada masyarakat tahun selanjutnya.

\section{Daftar Rujukan}

[1] Trianziani, S. (2018). Pelaksanaan Program Keluarga Berencana oleh Petugas Lapangan Keluarga Berencana (PLKB) di Desa Karangjaladri Kecamatan Parigi Kabupaten Pangandaran. Jurnal MODERAT, Volume 4, Nomor 4,November 2018, hlm 131-149 .DOI: http://dx.doi.org/10.25147/moderat.v4i4.1812.

[2] Sitorus, F.M., \& Siahaan, J. M. (2018). Pelayanan Keluarga Berencana Pasca Persalinan dalam Upaya Mendukung Percepatan Penurunan Angka Kematian Ibu. Midwifery Journal. DOI: https://doi.org/10.31764/mj.v3i2.505.

[3] Nurdela ,S. A. (2017). Aplikasi Peramalan Jumlah Kelahiran dengan Metode Jaringan Syaraf Tiruan. The Indonesian Journal of Public Health, Vol. 12 No. 2, 213 223. DOI: 10.20473/ijph.v12i1.2017.213-223.

[4] Mustopa, A., Wildah, S. K., Wijaya,G., Gata, W., \& Agustiani, S. (2020). Pengaruh Media Terhadap Pengambilan Keputusan Dalam Menjalankan Program Keluarga Berencana Dengan Algoritma Decision Tree. Paradigma - Jurnal Informatika dan Komputer, Vol. 22, No. 2.DOI: https://doi.org/10.31294/p.v22i2.8141.

[5] Adjie, J.M.S., Maya, G.,Manurung, C.,Hermawan, L. C., Elmida, M., Sofyan, M., Sujoko, A., Hafrida, I.,Aifiani, N. R.,Citarasmi, I. A.,Nugroho, P.,Masnawati., Melanie, H.,Amalia, D. O.,Merthawati, I. A. P., Milwiyandia., Rusmiyati.,Wiwit., Ekawati, D.,Husaini., Tiara, A. D., Mudjiati, I., Hutagalung, S., Kulsum, S.,Pakpahan, C. (2014). Pedoman Pelayanan Keluarga Berencana Pasca Persalinan di Fasilitas Kesehatan. Jakarta. Katalog Kementerian Kesehatan RI. 36-53.

[6] Alkronz, E.S., Moghayer, K. A.,Meimeh, M., Gazzaz, M., Nasser, B. S. A., \& Naser, S. S. A. (2019). Prediction of Whether Mushroom is Edible or Poisonous Using Backpropagation Neural Network. International Journal of Academic and Applied Research (IJAAR) Vol. 3 Issue 2, Pages:1-8.DOI:

http://dstore.alazhar.edu.ps/xmlui/handle/123456789/126.

Zola, Fatmi.,Nurcahyo, G. W.,\& Santony, J. (2018). Jaringan Syaraf Tiruan Menggunakan Algoritma Backpropagation untuk Memprediksi Prestasi Siswa. Jurnal Teknologidan Open $\begin{array}{llll}\text { Source } & \text { Vol. } & 1 & \text { No. }\end{array}$ 1.DOI: https://doi.org/10.36378/jtos.v1i1.12. 
[8] Syukri, \& Samsuddin. (2018). Pengujian Algoritma Artificial Neural Network (ANN) untuk Prediksi Kecepatan Angin. Jurnal Nasional Komputasi dan Teknologi Informasi Vol.2 No.1.DOI: https://doi.org/10.32672/jnkti.v2i1.1056.

[9] Aini, H., Haviluddin., Budiman, E., Wati, M., \& Puspitasari, N. (2019). Prediksi Produksi Minyak Kelapa Sawit Menggunakan Metode Backpropagation Neural Network. Sains, Aplikasi, Komputasi dan Teknologi Informasi, Vol 1, No 1, pp. 24 33.DOI: http://dx.doi.org/10.30872/jsakti.v1i1.2261.

24-

0] Setti, S., Sihotang, B. K., Wanto, A., Syafiq, M., \&Andriano, A. (2018). Analysis of Backpropagation Algorithms in Predicting WorldInternet Users.IOP Conf. Series: Journal of Physics: Conf. Series 1255. DOI:10.1088/17426596/1255/1/012018.

[11] Geng. R., Wang, X., Ye, N., \& Liu, J. (2018). A Fault [16] Prediction Algorithm Based on Rough Sets and Back Propagation Neural Network for Vehicular Networks. IEEE, VOLUME 6. DOI: 10.1109/ACCESS.2018.2881890.

[12] Qin, Y., \& Zheng, C. (2019). A Backpropagation Neural Network-based Flexural-tensile Strength Prediction Model for Asphalt Mixture in Cold Regions under Cyclic Thermal Stress. IIETA, Vol. 6, No. 3, pp. 433-436. DOI: https://doi.org/10.18280/mmep.060315.
[13] Lin, J. W., Chao, C. T., \&Chiou, J. S. (2018).Determining Neuronal Number in Each Hidden Layer Using Earthquake Catalogues as Training Data in Training an Embedded Back Propagation Neural Network for Predicting Earthquake Magnitude. IEEE, VOLUME 6. DOI: 10.1109/ACCESS.2018.2870189.

[14] Lubis, M. R. (2018). Analisis Jaringan Saraf Tiruan Backpropgation untuk Peningkatan Akurasi Prediksi Hasil Pertandingan Sepakbola. TECHSI: Vol. 10, No. 1. DOI: https://doi.org/10.29103/techsi.v10i1.560.

[15] Andriani, Y., Silitonga, H., \&Wanto, A. (2018). Analisis Jaringan Syaraf Tiruan untuk Prediksi Volume Ekspor dan Impor Migas di Indonesia. Jurnal Ilmiah Teknologi Sistem $\begin{array}{lllll}\text { Informasi } & 4 & \text { (1) } 2018 \quad 30-40 \text {. DOI }\end{array}$ :https://doi.org/10.26594/register.v4i1.1157.

16] Yanto, M., Mulyani. S. R., \& Mayola, L. (2019). Peramalan Jumlah Produksi Air dengan Algoritma Backpropagation Sebatik, 23(1), p. DOI: https://doi.org/10.46984/sebatik.v23i1.465.

[17] Sijabat, P. I., Yuhandri, Nurcahyo, G. W., Sindar, A. (2020). Algoritma Backpropagation Prediksi Harga Komoditi terhadap Karakteristik Konsumen Produk Kopi Lokal Nasional. Jurnal Teknologi Informasi \& Komunikasi Digital Zone, Volume 11, Nomor 1: 96-107. DOI: https://doi.org/10.31849/digitalzone.v11i1.3880ICC. 